\title{
Phenotypic and Genotypic Characterization of Some Pseudomonas sp. Associated with Burkholderia cepacia Isolated from Various Infected Fishes
}

\section{Manal I El-Barbary ${ }^{1 *}$ and Ahmed $\mathrm{M} \mathrm{Hal}^{2}$}

${ }^{1}$ Fish disease Lab., National Institute of Oceanography and Fisheries

${ }^{2}$ Genetics and Genetic Engineering Lab., National Institute of Oceanography and Fisheries

\begin{abstract}
This study aims to characterize $P$ seudomonas species that had been isolated from various naturally diseased fresh and marine water fishes, Nile tilapia, catfish, gilt-head bream, and Sea bass using phenotypic method, morphological and biochemical characteristics using API 20NE, and genotypic method based on 16S rRNA gene with some of the histopathological characteristics. Six of seven presumptive Pseudomonas sp. were successfully identified by API 20NE method to level species; they were identified as 2 P. fluorescens, one $P$. putida, one Pseudomonas sp and 3 Burkholderia cepacia while genotypically with 16S rRNA gene sequencing that proved successful for all the four pseudomonas isolates (three as $P$. fluorescens and one $P$. putida). The phylogenetic analysis placed the isolates in the genus Pseudomonas based on $99 \%$ homology. challenge test proved that, $P$. fluorescens and $P$. putida are to be classified as pathogenic for $O$. niloticus and they also exhibited clinical signs and mortality rates up to $70 \%$ and showed histopathological changes of both liver and kidney which lead to death. The antibiogram study showed no significant differences between $P$. fluorescens and $P$. putida which had intrinsically high sensitivity to nucleic acid synthesis inhibitors such as ciprofloxacin, norfloxacin, gatifloxacin, lomefloxacin. This study concluded that good overall agreement between phenotypic and genotypic identification procedures was found for the isolates with some minor differences in biochemical and physiological characteristics were observed between $P$. fluorescens strains, while the genotypic differences were significant observed between $P$. fluorescens and $P$. putida isolated from various fishes.
\end{abstract}

Keywords: Pseudomonas sp; API 20NE; 16S rRNA gene; Antibiogram; Histopathology; Fish

\section{Introduction}

Bacterial pathogens are naturally present in fish environment and under some specific stress conditions they are the etiological agents of the most important disease problems in aquaculture that induces mortalities and severe economic losses to fish farms [1]. Pseudomonas putida and $P$. fluorescens have been recorded as serious bacterial pathogens of fish and were characterized by causing high mortalities and economic losses among fish [2-5].

Pseudomonas fluorescens infection is widely distributed in aquaculture industries and is considered as one of the primary causes of bacterial hemorrhagic septicemia in fish and appears to be a stress related disease of freshwater and salt-water fish throughout the world [2]. It also causes severe economic losses and decreases fish farms efficiencies especially under culture conditions [6-8] such as overcrowding, low temperature where the highest natural mortalities were at $15^{\circ} \mathrm{C}$ to $20^{\circ} \mathrm{C}$, injuries as inappropriate handling and transportation and secondary pathogen of damaged fish tissues [9-14]. Austin [2] suggested the reason for the widespread incidence of Pseudomonas $s p$. in the aquatic environment may be due to its spread through the water, which acts as the major reservoir of infection.

Pseudomonas putida is a Gram-negative stain, slightly curved or straight rod bacterium, it also grows fast where oxygen is present [15]. The first isolation of P. putida was from ayu, and yellowtail fish [16-18], while, the first isolation from an infected common carp was in Turkey [19], where it caused ulcerative infection in fish.

Previous studies reported that $P$. putida is considered one of the serious bacterial pathogens that have endangered the aquaculture of various fishes such as rainbow trout, European eel, oyster toadfish and large yellow croaker [5,20-22]; thus, causing high mortality and resulting in severe economic loss [23].

On the other hand, Burkholderia cepacia previously known as
Pseudomonas cepacia, is a Gram-negative rod usually found in soil vegetation, and water [24,25]. P. cepacia was firstly described by Burkholder in 1950 [26]. Ramsey et al. [27] recorded that bacteria belonging to the genera Burkholderia are recognized as pathogenic in fish, however Kayis et al. [28] reported that Burkholderia cepacia was isolated from rainbow trout fish farms in Turkey (2006-2008) but was not a fish pathogen.

In Egyptian farms, the genus Pseudomonas has been described as a causative agent of diseases in fish where $P$. fluorescens, $P$. aeruginosa, $P$. putida and $P$. angulliseptica were identified in different species of fish as etiological agents of Pseudomonas septicemia [29-31]. The external changes related to infection by Pseudomonas sp. bacteria in different fish were fin rot, detached scales, hemorrhage and darkness of the skin, abdominal ascitis and exophthalmia [30,32]. The histopathological changes related to infection with Peudomonas sp. were observed in different organs as well, such as the liver, kidney, gills and skin of different infected fish [5,33-35].

The reliable and quick techniques for classification of pathogenic bacteria are important for successful diagnosis and control. Various studies have reported that the phenotypic identification methods are solely not enough for the classification of Pseudomonas sp. so, the genotypic identification systems are required to confirm the traditional

*Corresponding author: Manal I El-Barbary, Fish Diseases Laboratory, National Institute of Oceanography and Fisheries (NIOF), Egypt, Tel: 01006972324 E-mail: manal278@yahoo.com

Received July 22, 2017; Accepted August 22, 2017; Published August 25, 2017

Citation: El-Barbary MI, Hal AM (2017) Phenotypic and Genotypic Characterization of Some Pseudomonas sp. Associated with Burkholderia cepacia Isolated from Various Infected Fishes. J Aquac Res Development 8: 499. doi: 10.4172/21559546.1000499

Copyright: (c) 2017 El-Barbary Ml, et al. This is an open-access article distributed under the terms of the Creative Commons Attribution License, which permits unrestricted use, distribution, and reproduction in any medium, provided the original author and source are credited. 
Citation: El-Barbary MI, Hal AM (2017) Phenotypic and Genotypic Characterization of Some Pseudomonas sp. Associated with Burkholderia cepacia Isolated from Various Infected Fishes. J Aquac Res Development 8: 499. doi: 10.4172/2155-9546.1000499

identification of particularly potential dangerous Pseudomonads [36]. Molecular techniques using PCR-based methods allow fast, sensitive and exact identification of the bacteria that have been described for detection of fish diseases; $16 \mathrm{~S}$ rRNA gene is one of these important methods, especially when used alongside phenotypic characteristics for microbial identification in the diagnostic laboratory [37].

The aim of this study was to isolate and identify Pseudomonas sp. during outbreaks among fresh and marine water fish farms in Damietta Governorate and to compare between their phenotypic and genotypic characterizations during studies the morphological and biochemical characters, pathogencity, antibiotic susceptibility and phylogenetic analysis of identified pseudomonas together with their histological effects on the liver and kidney of challenged O. niloticus.

\section{Material and Methods}

\section{Isolation and characterization of bacterial isolates}

Bacterial isolates have been isolated from naturally diseased fishes namely Gilt-head bream, (Sparus auratus) and Sea bass (Dicentracchus labrax) which are important marine fish farmed in Deeba Triangle located in Damietta Governorate, Egypt along with African cat fish (Clarias garipinus) and Nila tilapia (Oreochromis niloticus) which have a high market value. Twenty fish samples, five of each type of fish, were collected during a disease outbreak in March 2015 and were transported to the laboratory in an icebox and processed during $2 \mathrm{~h}$ after collection. Samples from liver and kidney of collected fishes were streaked onto Pseudomonas base agar plates and incubated at $37^{\circ} \mathrm{C}$ for $24 \mathrm{~h}$. Some growing colonies were picked up in pure form where the identification of selective colonies was done by morphological and biochemical characters according to Austin [3] by using API 20NE (Biomérieux) for Gram-negative fish pathogens and they were identified to the genus pseudomonas.

\section{Bacterial genomic DNA purification protocol}

DNA isolation from cultured bacteria: The pure isolates were incubated overnight in tryptic soy broth at $37^{\circ} \mathrm{C}$, in order to isolate DNA. Bacterial genomic DNA was extracted using GeneJET Genomic DNA purification kit based on the manufacturer's instruction. The eluted DNA was used as a template for PCR detection of 16S rRNA gene.

\section{PCR and 16S rRNA gene sequencing}

Universal bacterial primers DG74 5'-AGGAGGTGATCCAACCGCA- ${ }^{\prime}$ and RW01 5' -AACTGGAGGAAGGTGGGGAT- ${ }^{\prime}$ ' were used for detection of $16 \mathrm{~S}$ rRNA [38]. The locations of primers were 15211540 and 1170-1189 (respectively). PCR reactions were done using 12.5 $\mu \mathrm{l}$ of DreamTaq Green PCR Master Mix (2x) , $1 \mu \mathrm{l}$ of each of DG74 and RW01 primers, $2 \mu$ of template DNA PCR grade water to reach the final volume of $25 \mu \mathrm{l}$ at room temperature. The amplification was performed using a thermal cycler with the following parameters: initial denaturation at $95^{\circ} \mathrm{C}$ for $5 \mathrm{~min}$, followed by 40 cycles of amplification (denaturation at $95^{\circ} \mathrm{C}$ for 30 s, annealing at $58^{\circ} \mathrm{C}$ for $30 \mathrm{~s}$, extension at $72^{\circ} \mathrm{C}$ for $30 \mathrm{~s}$ ) and a final extension step of $72^{\circ} \mathrm{C}$ for $10 \mathrm{~min}$. After amplification, $10 \mu$ of the PCR sample was loaded on a $1.5 \%$ agarose gel stained with ethidium bromide. PCR product was purified by QIAquick PCR purification kit and directly sequenced with a 3500/3500xL Genetic Analyzer (Applied Biosystems).

\section{Phylogenetic analysis}

The obtained sequences in this study were identified using BLASTN database. The $16 \mathrm{~S}$ rRNA genes of the four identified strains with 25 related species, from the GenBank database, were used to generate a phylogenetic tree; their accession numbers are shown in Figure 1. So, the analysis involved 29 nucleotide sequences which was led in MEGA5 [39] and phylogenetic tree was performed using Neighbor-Joining method [40] with 1,000 replicates of bootstrap test [41]. Evolutionary distances were calculated using the maximum composite likelihood method [42]. All gaps and missing data were deleted.

\section{Pathogenecity test}

An experimental infection study was carried out to examine the pathogenicity of four isolates of Pseudomonas sp. isolated from the liver of naturally infected fish for virulence to $O$. niloticus. Seventy healthy O. niloticus weighing $70 \mathrm{gm} \pm 2 \mathrm{gm}$ were obtained from El-Manzala fish farm, transferred and kept in ten glass aquaria provided with dechlorinated water with aeration; the fish were acclimatized for 2 weeks. Fish were fed with commercial pellet feed twice a day. Aquaria were divided into 5 groups each contained 14 fish. Each group was injected intraperitoneally (i.p.) with $0.5 \mathrm{ml}$ of a bacterial suspension from $P$. fluorescens (Pse, Psul and Pse172, groups B, C, D respectively) and $P$ putida (Psa groups E) that contained $10^{5} \mathrm{CFU} / \mathrm{ml}$ in Phosphate Buffered Saline (PBS). Fish in group A were injected with $0.5 \mathrm{ml}$ of sterile PBS alone (as a control group) using the same procedure. The virulence of the Pseudomonas strains was classified based on the development of clinical signs and mortality rates of fish that had been observed daily for 7 days. According to the severity of the mortality the virulence was considered positive + or ++ .

\section{Antibiotic susceptibility test}

Fifteen antimicrobial drugs were evaluated for efficiency against tested $P$. fluorescens and $P$. putida. The test was performed by the disc diffusion method in Muller Hinton Agar and incubated at $37^{\circ} \mathrm{C}$ for

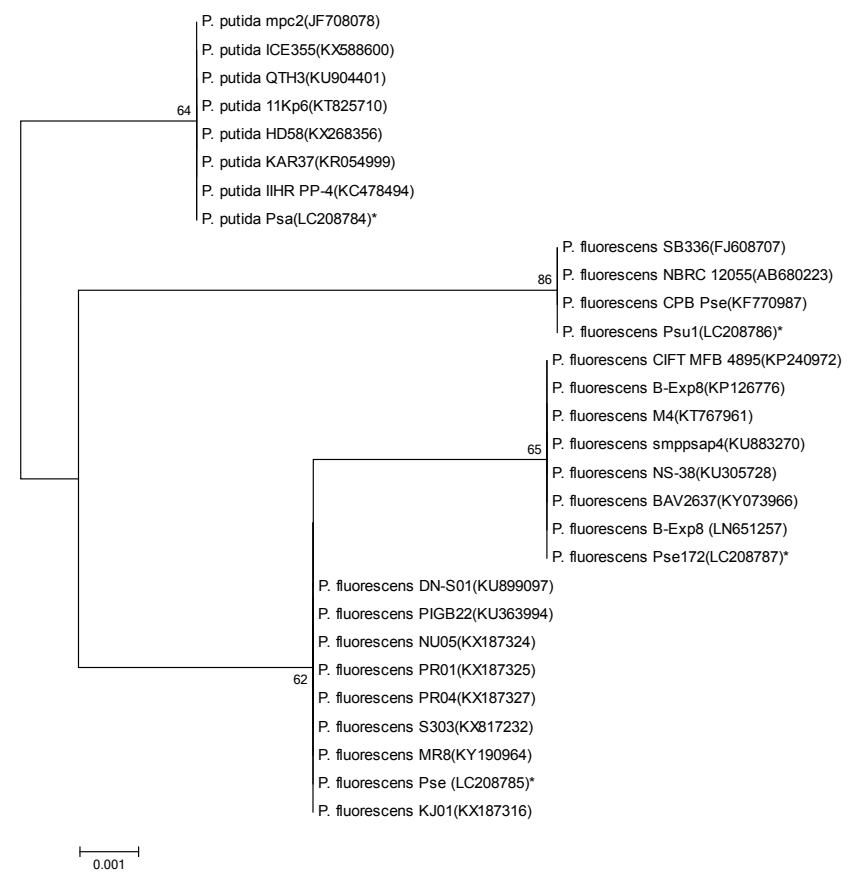

Figure 1: Phylogenetic tree of 16S rRNA gene sequences of $P$. fluorescens and $P$ putida isolated from various natural infected fishes with other related bacteria in GenBank database were constructed using the Neighbor-Joining method in MEGA5. The bacterial isolates of this study designated with an asterisk. 
Citation: El-Barbary MI, Hal AM (2017) Phenotypic and Genotypic Characterization of Some Pseudomonas sp. Associated with Burkholderia cepacia Isolated from Various Infected Fishes. J Aquac Res Development 8: 499. doi: 10.4172/2155-9546.1000499

$24 \mathrm{~h}$. There are fifteen antibiotics that include; two cell wall synthesis inhibitors [amoxicillin (AX) $20 \mu \mathrm{g}$ and tazobactam/piperacillin (TPZ) $110 \mu \mathrm{g}$ ], seven protein synthesis inhibitors [erythromycin (E) $15 \mu \mathrm{g}$, gentamicin $10 \mu \mathrm{g}$, streptomycin (S) $10 \mu \mathrm{g}$, oxytetracycline (OTC) $30 \mu \mathrm{g}$, tobramycin (TOB) $10 \mu \mathrm{g}$, kanamycin (KA) $30 \mu \mathrm{g}$, azithromycin (AZM) 15] and six nucleic acid synthesis inhibitors [ciprofloxacin (CIP) $5 \mu \mathrm{g}$, gatifloxacin (GAT) $5 \mu \mathrm{g}$, sulfamethoxazole (SXT) $25 \mu \mathrm{g}$, lomefloxacin (LOM) $10 \mu \mathrm{g}$, nalidixic acid (NA) $30 \mu \mathrm{g}$ and norofloxacin (NOR ) $10 \mu \mathrm{g}]$ as listed in Table 1. Pseudomonas strains were characterized as sensitive, intermediate or resistant according to the size of the inhibition zones around the discs [43].

\begin{tabular}{|c|c|c|c|c|c|}
\hline \multirow{2}{*}{ Test } & \multicolumn{2}{|c|}{ P. fluorescens } & \multirow{2}{*}{$\begin{array}{c}\text { P. putida } \\
\text { Psa }\end{array}$} & \multirow{2}{*}{$\begin{array}{c}\text { P. species } \\
\text { Psu1 }\end{array}$} & \multirow{2}{*}{$\begin{array}{c}\text { B. cepacia } \\
\text { P5-P7 }\end{array}$} \\
\hline & Pse & Pse 172 & & & \\
\hline Utilization of $\mathrm{NO}_{3}$ & - & - & - & - & $+v$ \\
\hline Indol production & - & - & - & - & - \\
\hline $\begin{array}{c}\text { Glucose } \\
\text { fermentation }\end{array}$ & - & - & - & - & - \\
\hline $\begin{array}{c}\text { Arginine } \\
\text { dihydrolase }\end{array}$ & + & - & + & - & - \\
\hline Urease & - & - & - & - & - \\
\hline$\beta$ glucosidase & + & - & - & - & + \\
\hline Gelatin hydrolysis & + & + & - & - & + \\
\hline $\begin{array}{l}\text { O-nitrophenyl- } \beta \text { - } \\
\text { galactopyranoside }\end{array}$ & - & - & - & - & + \\
\hline \multicolumn{6}{|l|}{$\begin{array}{l}\text { Utilazition of } \\
\text { sugar }\end{array}$} \\
\hline Glucose (GLU) & + & + & + & + & + \\
\hline Arabinose (ARA) & - & - & - & - & $+\mathrm{v}$ \\
\hline Manose (MNE) & + & + & - & + & + \\
\hline Manitol (MAN) & + & + & - & + & + \\
\hline $\begin{array}{c}\text { N-Acetyl } \\
\text { glucosamine } \\
\text { (NAG) }\end{array}$ & - & + & - & - & + \\
\hline Maltose (MAL) & - & - & - & - & $+\mathrm{v}$ \\
\hline $\begin{array}{l}\text { K gluconate } \\
\text { (GNT) }\end{array}$ & + & + & + & + & + \\
\hline Capric acid (CAP) & + & + & + & + & + \\
\hline Adipic acid (ADI) & - & - & - & - & - \\
\hline Malate(MLT) & + & + & + & + & + \\
\hline $\begin{array}{c}\text { Tri sodium citrate } \\
\text { (CIT) }\end{array}$ & + & + & + & + & + \\
\hline $\begin{array}{c}\text { Phenyl acetic acid } \\
\text { (PAC) }\end{array}$ & + & - & + & - & + \\
\hline OX & + & + & + & + & + \\
\hline \multirow{3}{*}{ API 20NE code } & \multirow{3}{*}{556457} & \multirow{3}{*}{56555} & \multirow{3}{*}{140455} & \multirow{3}{*}{46455} & 1477757 \\
\hline & & & & & 454557 \\
\hline & & & & & 456547 \\
\hline
\end{tabular}

Table 1: Phenotypic characteristics of Pseudomonas and Burkholderia species..

\begin{tabular}{|c|c|c|c|c|}
\hline \multirow{2}{*}{ Isolates } & \multirow{2}{*}{ Fish species } & \multicolumn{2}{|c|}{ Identification method } & \multirow{2}{*}{$\begin{array}{c}\text { Accession } \\
\text { number }\end{array}$} \\
\hline & & API 20NE & 16S rRNA & \\
\hline Pse & $\begin{array}{l}\text { Gilthead bream } \\
\text { (S. auratus) }\end{array}$ & P. fluorescens & P. fluorescens & LC208785 \\
\hline Psu1 & $\begin{array}{l}\text { Nile tilapia (O. } \\
\text { niloticus) }\end{array}$ & Pseudomonas sp & P. fluorescens & LC208786 \\
\hline Pse172 & $\begin{array}{l}\text { African cat fish } \\
\text { (C. garipinus) }\end{array}$ & P. fluorescens & P. fluorescens & LC208787 \\
\hline Psa & $\begin{array}{c}\text { Sea bass }(D . s \\
\text { labrax })\end{array}$ & P. putida & P. putida & LC208784 \\
\hline
\end{tabular}

Table 2: Comparison of API 20NE method and 16S rRNA identifications of Pseudomonas strains.

\section{Histopathological examination of $\boldsymbol{O}$. niloticus liver and kidney}

Liver and kidney specimens were taken from both experimentally infected $O$. niloticus and control on the seventh day post infection. The samples were fixed in $10 \%$ formalin and the histopathological examination was performed according to Roberts [44] where the tissue sections were stained with hematoxylin-eosin (HE).

\section{Results}

\section{Phenotypical characterization and hemolytic activity on blood agar}

Some presumptive Pseudomonas colonies that were selected from PBA plates were identified morphologically as Gram-negative rod motile bacteria. Biochemically; bacteria were oxidase positive and unable to ferment glucose, thus characterized as Pseudomonas genus. Only seven of the presumptive Pseudomonas isolates were identified using API 20NE method. All isolates were positive for utilization of citrate, glucose, potassium gluconate, capric acid and malate but negative for indole production. Whereas the results of the arabinose, maltose, manose, manitol, phenyl acetic acid and gelatin liquefaction tests found variables among the isolates (Table 1).

The results of API 20NE tests were interpreted using the 'apiweb' program (BioMerieux). According to the standard tests and phenotypic characterization by the API 20NE identification system, similar to API 20NE code, the strains identified by API 20NE were of four different species; P. fluorescens (Pse, and Pse172), P. putida (Psa), Pseudomonas sp. (Psu1) and Burkholderia cepacia (P5, P6, P7) with different API 20NE code; 0556457, 0056555, 0140455, and 0046455 for Pseudomonas strains while Burkholderia cepacia showed 1477757, 0454557 and 0456547 codes (Table 1). The specific media, PAB, is specific for Pseudomonas sp. and sometimes Burkholderia cepacia grows on it. The method was successful for 6 out of the 7 tested isolates and Burkholderia cepacia was isolated only from marine fish Gilt-head bream and Sea bass.

\section{Identification by $16 S$ rRNA and sequencing}

DG74 and RW01 primers were used to amplify of $16 \mathrm{~S}$ rRNA of bacterial isolates, with amplicon size $\sim 370 \mathrm{bp}$. The four-bacterial species belonged to family Pseudomonadaceae. Four isolates were collected and identified by $16 \mathrm{~S}$ rRNA (Pse, Pse1, Psu172 and Psa). The amplified nucleotide sequence showed 99\% homology with the $16 \mathrm{~S}$ rDNA sequence of $P$. fluorescens and $P$. putida. The results of $16 \mathrm{~S}$ rRNA sequence correlated with phenotypic classification of the Pseudomonas strains. Overall good agreement between phenotypic and genotypic identification procedures was found for the 3 isolates (Pse, Pse172 and Psa). In fact, these isolates were genotypically identified as $P$. fluorescens and $P$. putida. However, discordance of identification between phenotypic methods and 16S rRNA sequence analysis was observed in strain Psul that was identified based on API 20NE as Pseudomonas spp. while, $16 \mathrm{~S}$ rRNA sequencing identified as $P$. fluorescens (Table 2). The result of 16S rRNA sequence was deposited into GenBank under the accession number LC208785, LC208786, LC208787 (Pse, Psu1, and Pse172 as $P$. fluorescens respectively) and LC208784 (P. putida, Psa). The closer relationships among sequences of $16 \mathrm{~S}$ rRNA were grouped with each other in phylogenetic tree, where phylotypes were distributed in the branches (Figure 1).

The cluster of the Pseudomonas fluorescens harbored three bacterial isolates which were isolated from Sparus auratus, Clarias garipinus and O. niloticus (Pse, Psul and Pse172). They showed 99\% of homology 
Citation: El-Barbary MI, Hal AM (2017) Phenotypic and Genotypic Characterization of Some Pseudomonas sp. Associated with Burkholderia cepacia Isolated from Various Infected Fishes. J Aquac Res Development 8: 499. doi: 10.4172/2155-9546.1000499

with P. fluorescens in GenBank (acc. nos. KF187316, KY190964 for Pse, KF776987, AB680223 for Psu1 and LN651257, KY073966 for Pse172, ). However, one bacterial isolate of P. putida (LC208784) was closely related with P. putida in GenBank (accession nos. KC478494 and KR054999).

\section{Antibiotic sensitivity}

Antibiotic susceptibility study showed that all isolates had intrinsically high sensitivity to ciprofloxacin, norfloxacin, gentamycin, gatifloxacin, lomefloxacin and kanamycin except $P$. putida (Psa) that reflected an intermediate reaction with gatifloxacin and lomefloxacin. However, these isolates were resistant to sulfamethoxazole, erythromycin, amoxicillin, tazobactam/piperacillin and nalidixic acid and were intermediate with oxytetracyclin. Other antibiotics such as tobramycin, streptomycin and azithromycin showed variation in their effects as antibacterial agents among bacterial isolates (Table 3).

\section{Pathogenecity for O. niloticus}

Fish groups injected with $P$. fluorescens (Pse, Psul and Pse172) and P. putida (Psa) revealed mortality ranging from $65 \%$ to $70 \%$ within 7 days (Table 4). Therefore, these isolates were pathogenic for O. niloticus and were classified as virulent for fish (+). They also exhibited external hemorrhage, skin ulceration and dark pigmentation while no mortality or clinical signs were observed during the experiment in control fish (group A).

\section{Histopathological examination}

No histological changes were observed in the liver and kidney of control fish (A) (Plate 1a and 1d). The histopathological changes of the $O$. niloticus infected with pathogenic $P$. fluorescens (group B) were

\begin{tabular}{|c|c|c|c|c|}
\hline \multirow[b]{2}{*}{ Antibiotic Disc } & \multicolumn{4}{|c|}{ Response of bacterial strains to different antibiotics } \\
\hline & $\begin{array}{l}\text { P. fluorescens } \\
\text { Pse }\end{array}$ & $\begin{array}{c}\text { P. fluorescens } \\
\text { Psu1 }\end{array}$ & $\begin{array}{c}\text { P. fluorescens } \\
\text { Pse172 }\end{array}$ & $\begin{array}{l}\text { P. putida } \\
\text { Psa }\end{array}$ \\
\hline Norfloxacin & S & S & S & $\mathrm{S}$ \\
\hline Cirprofloxacin & S & S & S & S \\
\hline Gatifl oxacin & S & S & $\mathrm{S}$ & 1 \\
\hline Lomefloxacin & $S$ & $S$ & $\mathrm{~S}$ & 1 \\
\hline Nalidixic Acid & $\mathrm{R}$ & $\mathrm{R}$ & $\mathrm{R}$ & $\mathrm{R}$ \\
\hline Gentamycin & S & $\mathrm{S}$ & $\mathrm{S}$ & $\mathrm{S}$ \\
\hline Tobramycin & I & $\mathrm{S}$ & I & $\mathrm{R}$ \\
\hline Kanamycin & S & $S$ & $\mathrm{~S}$ & $S$ \\
\hline Streptomycin & 1 & $S$ & $S$ & 1 \\
\hline Azithromycin & $\mathrm{R}$ & 1 & $\mathrm{R}$ & I \\
\hline Erythromycin & $\mathrm{R}$ & $\mathrm{R}$ & $\mathrm{R}$ & $\mathrm{R}$ \\
\hline Oxytetracyclin & I & I & I & I \\
\hline $\begin{array}{l}\text { Sulfamethoxa- } \\
\text { zole }\end{array}$ & $\mathrm{R}$ & $\mathrm{R}$ & $\mathrm{R}$ & $\mathrm{R}$ \\
\hline Amoxicillin & $\mathrm{R}$ & $\mathrm{R}$ & $\mathrm{R}$ & $\mathrm{R}$ \\
\hline $\begin{array}{l}\text { Tazobactam/ } \\
\text { piperacillin }\end{array}$ & $\mathrm{R}$ & $\mathrm{R}$ & $\mathrm{R}$ & $\mathrm{R}$ \\
\hline
\end{tabular}

S: susceptible; I: intermediate susceptible; R: resistant.

Table 3: Antibacterial activity of different antibiotics against $P$. fluorescens and $P$. putida.

\begin{tabular}{|l|c|c|}
\hline \multicolumn{1}{|c|}{ Bacterial isolate (Groups) } & Fish mortality/isolate & Pathogenicity $\%$ \\
\hline \multicolumn{1}{|c|}{ Control (A) } & $0 / 14(-)$ & 0.00 \\
\hline P. fluorescens isolate; Pse (B) & $9 / 14(+)$ & 65 \\
\hline P. fluorescens isolate; Psu1 (C) & $9 / 14(+)$ & 65 \\
\hline P. fluorescens isolate; Pse172 (D) & $9 / 14(+)$ & 65 \\
\hline P. putida isolate; Psa (E) & $10 / 14(+)$ & 70 \\
\hline +: Isolates positive; -: Isolates negative & & \\
\hline
\end{tabular}

Table 4: Phenotypic differences among virulent bacterial isolates.

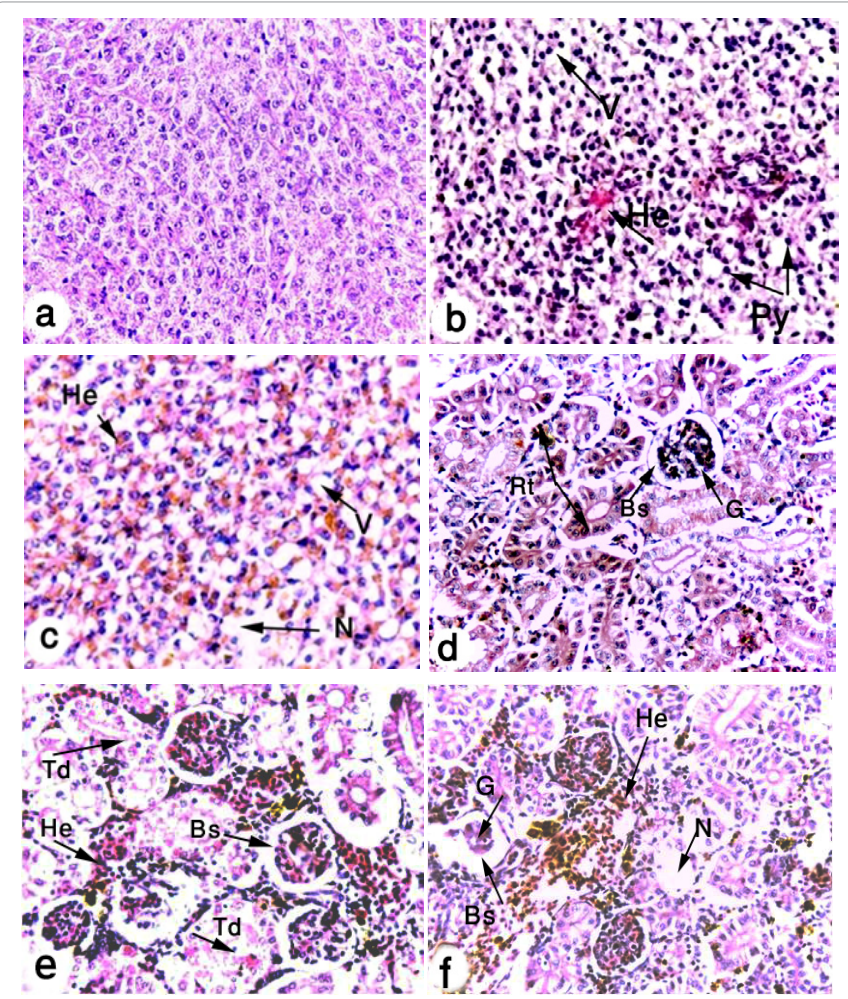

Plate (1a-1f): Histopathological changes of the liver and kidney of $O$. niloticus groups (A, B, and D) stained with $\mathrm{H}$ \& $\mathrm{E} ;(\mathrm{a}, \mathrm{d}) \mathrm{A}$ (control group) normal structure tissue of both liver and kidney $(x 400)$. (b) Group B hemolysis between hepatocytes, cytoplasmic vacuolation and pyknotic nucleus of the liver ( $x 400$ ). (c) Group D severe lipid vacuoles and necrosis of hepatocytes with hemolysis (x400). (e) Group B tubular degeneration with interstitial mononuclear cell infiltration, disconnection of renal tubules, dilation in Bowman's space and hemorrhage between renal tubules of the kidney (x400). (f) Group D necrosis area and hemorrhage between renal tubules, dilation in Bowman's space and decrease of the glomerular component (x400). N: Necrosis; Hs: Hemolysis; V: Vacuolar degeneration; pk: Pyknosis; G: Glomerulus; BS: Bowman's Space; If: Infiltration; RT: Renal Tubular; Rd: Renal tubular degeneration; He: Hemorrhage.

hemolysis between hepatocytes with cytoplasmic vacuolation and pyknotic nucleus in liver hepatocytes (Plate $1 \mathrm{~b}$ ). While O. niloticus injected with pathogenic P. putida (group E) showed severe lipid vacuoles with hepatocytes necrosis and severe vacuolar degeneration, between hepatocytes in liver (Plate 1c). Kidney of O. niloticus infected with pathogenic $P$. fluorescens had tubular degeneration with interstitial mononuclear cell infiltration in addition to, disconnection of renal tubules, hemorrhage between renal tubules, decrease of the glomerular component and degeneration and necrosis of renal tubular and dilation in Bowman's space (Plate 1e). Similar lesions were observed in kidney of $O$. niloticus injected with $P$. putida which showed hemorrhage and necrosis area between renal tubules, dilation in Bowman's space and decrease of the glomerular component (Plate 1f).

\section{Discussion}

During the spring of 2015 a disease outbreak occurred among some of the marine and freshwater fish farms where the fish died. The typical clinical signs were skin ulceration and hemorrhage. The causative bacteria isolated from these fish farms were identified as $P$. fluorescens and P. putida according to phenotypical characteristics and sequence of $16 \mathrm{~S}$ rRNA. These findings agree with those of Eissa et al. and EL-Hady and Samy $[30,45]$ who reported that P. fluorescens, $P$. 
putida with other species are an aquaculture pathogen that can infect various species of fish, including O. niloticus, Cyprinus carpio. In the current study, the clinical and postmortem findings for infected fishes that showed hemorrhages and ulcer on the skin, dark pigmentation and abdominal distention, similar lesions as hemorrhages over all of the fish body, tail and fins rot, scale separation, skin ulceration and abdominal swelling of naturally infected fishes were recorded by Eissa et al., Okaeme and Hanna et al. [30,32,35]. Some of these lesions caused by $P$. putida are similar to a disease caused by Flavobacterium columnare, F. psychrophilum and motile Aeromonas sp. [46-48], where the ulcers caused by $P$. putida can be observed almost exclusively on the dorsal surface of the fish [48]. This result may give a necropsy hint for differential diagnosis of the disease [5].

The results in Table 1 showed that, all isolates identified as Pseudomonas and B. cepacia along with all Pseudomonas were characterized by Gram-negative motile rods with cytochrome oxidase. These findings agree with those of Altinok et al., Nathan et al. [5,49] who had observed that Pseudomonas species are Gram-negative, oxidase positive and rod shaped. P. fluorescens showed variation in some phenotypic tests such as gelatin hydrolysis where it has an ability to hydrolyze gelatin in contrast to $P$. putida. This result agrees with the findings of Krieg and Holt [15] who reported that $P$. fluorescens can be discerned from $P$. putida through its ability to hydrolyze gelatin.

In this study, the identification of all Pseudomonas species by API 20NE and phenotypic characters revealed good identification. Isolates Pse and Pse172 revealed profile of 0556457, 0056555 in the API 20NE systems and were identified as $P$. fluorescens. While Psa revealed profile of 0140455 of $P$. putida but the isolate of pseudomonas Psu1 revealed a profile 0046455 and identified as Pseudomonas species, it was however identified as $P$. fluorescens by $16 \mathrm{~S}$ rRNA gene. These results agree with those of Altinok et al. [5] who identified P. putida by API 20NE with a profile number of 0140455 but it was 0142457 in the study of Kayış and $\operatorname{Er}[50]$.

In addition, isolates were well identified at species level by API 20NE method and 16S rRNA sequences, and they showed good overall agreement. On the other hand, API 20NE identification gave incomplete result at species level that was identified as Pseudomonas sp. however; it was identified as $P$. fluorescens (Psu1) based $16 \mathrm{~S}$ rDNA. This result agrees with Uğur et al. [51] who reported that in rare instances, (3/17), $16 \mathrm{~S}$ rRNA sequences of two isolates were identified as $P$. fluorescens based on phenotypic characters, revealed that they were P. putida (96\%), where these results indicated that the procedures for the identification of Pseudomonas sp. based on phenotypic characteristics should be additionally verified by the molecular methods to obtain results that are meaningful as well as accurate. Many studies have suggested that the phenotypic classification techniques are solely not adequate for identification of Pseudomonas sp., though, overall, the API 20NE was successful in the identification of all the four Pseudomonas strains that had been isolated from fish. That is in agreement with Wiedmann et al. [52], who reported that API 20NE resulted in the proper identification of Pseudomonas isolates to the species level.

The analysis of 16S rRNA gene presented fast and accurate identification of the detected bacteria [53-55]. Many groups of primers have been designed to amplify various regions of $16 \mathrm{~S} \mathrm{rDNA}$ and have been explained to have different specificities and susceptibility [38].

The present study used PCR technique targeting 16S rRNA for detection of bacterial isolates from infected fish through universal primers (RW01 and DG74), that was reported to be a sensitive screening technique to detect the bacterial communities' $[38,56]$.
The phylogenetic analysis placed the bacterial isolates in the family Pseudomonadaceae based on $99 \%$ homology because $>98.7 \%$ of $16 \mathrm{~S}$ rRNA gene sequence similarity are not considered to be different species [57].

The results of the pathogenicity study exhibited that $O$. niloticus challenged with $P$. fluorescens and $P$. putida (Pse, Psu1, Pse172 and Psa) caused a mortality rate up to $70 \%$ within 7 days (Table 4 ). Therefore, the Pseudomonas strains were pathogenic for O. niloticus, these findings agree with Austin and Austin; Toranzo et al. and Altinok et al. [3-5], but disagree with some results of Eissa et al. [30] who observed that $P$. putida showed mortality rates of $86.66 \%$ in the injected fish. While $P$. fluorescens biovar I, II and III strains were nonpathogenic also, Altinok et al. [5] reported that mortality of fish injected with $P$. putida was $45 \%$. The antibiotic susceptibility study recorded that $P$. fluorescens and $P$. putida exhibited sensitivity to ciprofloxacin, norfloxacin, gentamycin, gatifloxacin, lomefloxacin and kanamycin, that was found to be consistent with Eissa et al. [30] who reported that most strains of $P$. putida, $P$. anguilliseptica and $P$. aureginosa were sensitive to Avatryl and Amikicin, Novobiocin, Erythromycin, Gentamicin, and Sulfa-trimethoprime. Also, Altinok et al. [5] reported that $P$. putida has high resistance to Ampicillin, Erythromycin, Chloramphenicol, Tetracycline, Naladixic acid Rifampicin and Streptomycin. Thus, it is difficult to use these antibiotics to treat the fish infected with $P$. putida. In addition, $P$. fluorescens exhibited complete resistance to penicillin and erythromycin and susceptibility to oxytetracycline and amikacin more than kanamycin, neomycin and gentamicin [58]. Also, Darak and Barde [59] reported that $P$. fluorescens was very sensitive to kanamycin, nalidixic acid, gentamicin, neomycin, less sensitive to amikacin and tetracycline, and chlorophenicol and the least sensitive to oxytetracycline, erythromycin and penicillin.

The histological changes in the liver and kidney of the O. niloticus infected by pathogenic $P$. fluorescens and $P$. putida in the current study are similar to the findings of Amosu; Hanna et al. [34,35] who observed pathological lesions in the liver of African catfish, which were inoculated with $P$. aeruginosa, these lesions included widespread hepatic degeneration, focal area of cellular infiltration, disorganization of the hepatic cells and area of necrosis with hyperplesia in the wall of the blood vessels.

Altinok et al. [5] observed that, in rainbow trout the skin ulcer was initially described by sloughed off epithelia and epithelial necrosis while in the developed form of $P$. putida disease most of all the skin layers down to the epidermis were lost. Also, Kumaran et al. [60] reported that the infected Sea bass with Pseudomonas sp. showed irregularly shaped nuclei of hepatocytes and focal necrosis, eosinophilic granulocytes and erythrocytes.

\section{Conclusion}

In conclusion, API 20NE gave a good identification of Pseudomonas isolates. Using $16 \mathrm{~S}$ rRNA gene sequencing proves that diagnosing fish's bacterial diseases is important for successful epidemiological studies and disease control. The results concluded that some minor differences in biochemical and physiological characteristics were observed between $P$. fluorescens strains, while the phenotypic and genotypic differences were observed between $P$. fluorescens and $P$. putida isolated from fish. Also, pathogenic $P$. fluorescens compared to $P$. putida is more sensitive to ciprofloxacin, norfloxacin, gentamycin, gatifloxacin, lomefloxacin and kanamycin.

\section{References}

1. Olsson JC, Joborn A, Westerdahl A, Blomberg L, Kjelleberg S, et al. (1998) 
Citation: El-Barbary MI, Hal AM (2017) Phenotypic and Genotypic Characterization of Some Pseudomonas sp. Associated with Burkholderia cepacia Isolated from Various Infected Fishes. J Aquac Res Development 8: 499. doi: 10.4172/2155-9546.1000499

Survival, persistence and proliferation of Vibrio anguillarum in juvenile turbot, Scophthlmus maximus (L.), intestine and faeces. J Fish Dis 21: 1-9.

2. Austin B, Austin DA (1999) Bacterial fish pathogens. Disease of farmed and wild fish. Springer-Praxis, Chichester, UK.

3. Austin B, Austin DA (2007) Bacterial fish pathogens, diseases of farmed and wild fish. (4th edn), Praxis Publishing Ltd, Chichester, UK.

4. Toranzo AE, Magarinos B, Romalde JL (2005) A review of the main bacterial fish diseases in mariculture systems. Aquaculture 246: 37-61.

5. Altinok I, Kayis S, Capkin E (2006) Pseudomonas putida infection in rainbow trout. Aquaculture 261: 850-855.

6. Kitao T, Aoki T, Fukudome M, Kawano K, Wada Yo, et al. (1993) Serotyping of Vibrio anguillarum isolated from fresh water fish in Japan. J Fish Dis 6: 175181.

7. Stoskopf KM (1993) Fish Medicine. WB Saunders Compony, Harcourt Brace Jovanovich, Inc, USA.

8. Fayed AA, Khater AA, Omyima A, Abboud Y (1997) Pseudomonas septicemia encountered in some ornamental fish. Alex J Vet Sci 13: 93-100.

9. Allen DA, Austin B, Colwell RR (1983) Numerical taxonomy of bacterial isolates associated with a freshwater fishery. J Gen Microbiol 129: 2043-2062.

10. Frerichs GN, Holliman A (1991) Isolation of a brown pigment-producing strain of Ps. Fluorescencs cross reacting with Aeromonas salmonicida diargnostic antisera. J Fish Dis 14: 599-601.

11. Aly SE (1994) Pathological studies on some fish in Suez Canal area. Fac of Vet Med Suez Canal Univ.

12. Domenech A, Fernandez-Garayzabol JF, Garcia JA, Cutuli MT, Blanco M, et al. (1999) Association of Pseudomonase anguilliseptica infection with winter disease in sea bream, Sparus aurata L. J Fish Dis 22: 69-71.

13. Austin B, Austin D (1993)Bacterial fish pathogens (2nd edn) Pseudomonadaceae representatives.

14. Otte E (1963) Die heutigen Ansichten uber die Atiologie der Infektiosen Bachwassersucht der Karpfen. Wien Tierarztl Monatsschr 50: 995-1005.

15. Krieg NR, Holt JG (1984) Bergey's Manual of Systematic Bacteriology.

16. Kusuda R, Toyoshima T (1976) Characteristics of a pathogenic Pseudomonas isolated from cultured yellowtail. Fish Pathol 1: 133-139.

17. Muroga K (1990) Bacterial infections in cultured fishes in Japan. The Second Asian Fisheries Forum. Asian Fisheries Society, Manila, Philippines.

18. Wakabayashi H, Sawada K, Ninomiya K, Nishimori E (1996) Bacterial hemorrhagic ascites of ayu caused by Pseudomonas sp. Fish Pathol 31: 239240 .

19. Aydin S, Ciltas A, Erman Z (1998) Pseudomonas putida infections in scattered mirror carp (Cyprinus carpio) and Gold fish (Carassius auratus). In: First International Symposium on Fisheries and Ecology Proceedings, Trabzon, Turkey.

20. Smolowitz R, Wadman E, Chikarmane HM (1998) Pseudomonas putida infections of the Oyster toadfish (Opsanus tau). Biol Bull 195: 229-231.

21. Fan HP (2001) Study on the gill-rot disease of Anguilla anguilla infected by Pseudomonas putida. J Fish China 25: 147-150.

22. Shen JY, Yu XP, Pan XY, Xu WJ, Yin WL, et al. (2008) Isolation and identification of Pseudomonassis pathogen from cultured Pseudosciaena crocea. Mar Fish Res 29: 1-6.

23. Mao Z, Qiu Y, Zheng L, Chen J, Yang J (2012) Development of a visual loopmediated isothermal amplification method for rapid detection of the bacterial pathogen Pseudomonas putida of the large yellow croaker (Pseudosciaena crocea). J Microbiol Methods 89: 179-184.

24. Govan JR, Hughes JE, Vandamme P (1996) Burkholderia cepacia: Medical, taxonomic and ecological issues. J Med Microbiol 45: 395-407.

25. Holmes A, Nolan R, Taylor R, Finley R, Riley M, et al. (1999) An epidemic of Burkholderia cepacia transmitted between patients with and without cystic fibrosis. J Infect Dis 179: 1197-1205.

26. Burkholder WH (1950) Sour skin, a bacterial rot of onion bulbs. Phytopathology 40: $115-117$
27. Ramsey $\mathrm{AH}$, Skonieczny $\mathrm{P}$, Coolidge DH, Kurzynski TA, Proctor ME et al. (2001) Burkholderia cepacia lower respiratory tract infection associated with exposure to a respiratory therapist. Infect Control Hosp Epidemiol 22: 423-426.

28. Kayis S, Capkin E, Balta F, Altinok I (2009) Bacteria in Rainbow Trout (Oncorhynchus mykiss) in the Southern Black Sea Region of Turkey- A survey. Isr J Aquacult-Bamid 61: 339-344.

29. Sakar SFM, Azza MMA (2008) Contribution on Pseudomona septicemia caused by Ps. anguilliseptica in cultured Oreochromis niloticus. Fish Diseases Dept., Central lab for Aquaculture Research, Abbassa, Agriculture Research Center, Egypt

30. Eissa NME, Abou El-Ghiet EN, Shaheen A, Abbass A (2010) Characterization of Pseudomonas species isolated from Tilapia "Oreochromis niloticus" in Qaroun and Wadi-El-Rayan Lakes, Egypt. Global Veterinaria 5: 116-121.

31. El-Nagar RMA (2010) Bacteriological studies on pseudomonas microorganisms in cultured. Fac Vet Med Zag University.

32. Okaeme AN (1989) Bacteria associated with mortality in tilapias Heterobranchus bidorsalis, and Clarias lazera in indoor hatcheries and outdoor ponds. J Aquacult Trop 4: 143-146.

33. Khalil SA, Khalil RH, Saad TT, Safaa MH (2010) Studies on Pseudomonas septicemia among cultured Oreochromus niloticus. J Arabian aquaculture society 5: 55-64.

34. Amosu OA (2012) Histopathological studies of Clarias gariepinus (Burchell,1822) post fingerlings inoculated with Pseudomonas aeruginosa.

35. Hanna MI, El-Hady MA, Ahmed HA, Elmeadawy SA, Kenwy AM (2014) A contribution on Pseudomonas aeruginosa infection in African Catfish (Clarias gariepinus). Res J Pharm Biol Chem Sci 5: 575-588.

36. Alatossava PM, Alatossava T (2006) Phenotypic characterization of raw milk associated psychrotrophic bacteria. Microbiol Res 161: 334-346.

37. Buller NB (2004) Bacteria from fish and other aquatic animals: A practical identification manual. CABI Publishing, Oxfordshire, UK.

38. Greisen K, Loeffelholz M, Purohit A, Leong D (1994) PCR primers and probes for the $16 \mathrm{~S}$ ribosomal RNA gene of most species of pathogenic bacteria, including bacteria found in cerebrospinal fluid. J Clin Microbiol 32: 335-351.

39. Tamura K, Peterson D, Peterson N, Stecher G, Nei M, et al. (2011) MEGA5 Molecular evolutionary genetics analysis using maximum likelihood, evolutionary distance, and maximum parsimony methods. Mol Biol Evol 28 2731-2739.

40. Saitou N, Nei M (1987) The neighbor-joining method: A new method for reconstructing phylogenetic trees. Mol Biol Evol 4: 406-425.

41. Felsenstein J (1985) Confidence limits on phylogenies: An approach using the bootstrap. Evolution 39: 783-791.

42. Tamura K, Nei M, Kumar S (2004) Prospects for inferring very large phylogenies by using the neighbor-joining method. PNAS (USA) 101: 11030-11035.

43. CLSI (2010) Performance standards for antimicrobial susceptibility testing. $20^{\text {th }}$ Informational Supplement. Clinical and Laboratory Standards Institute. Wayne, PA, USA.

44. Roberts RJ (2004) Fish pathology, (3rd edn) Philadelphia, PA, USA

45. El-Hady MA, Samy AA (2011) Molecular typing of Pseudomonas species isolated from some cultured fishes in Egypt. Global Veterinaria 7: 576-580.

46. Wood JW (1974) Diseases of pacific salmon, their prevention and treatment (2nd edn). Washington Department of Fisheries, Olympia, USA

47. Holt RA, Rohovec JS, Fryer JL (1993) Bacterial cold-water disease. Bacterial Diseases of Fish. Blackwell Scientific Publications, Oxford, UK.

48. Plumb JA (1999) Health maintenance and principal microbial diseases of cultured fishes. lowa State University Press, Ames, lowa, USA

49. Nathan $P$, Rathinam X, Kasi M, Rahman ZA, Subrama-niam S (2011) A pilot study on the isolation and biochemical characterization of Pseudomonas from chemical intensive rice ecosystem. Afr J Biotechnol 10: 12653-12656.

50. Kayış S, Er A (2014) Skin lesions on different fish species caused by bacteria Ege J Fish Aqua Sci 31: 55-59.

51. Uğur A, Ceylan Ö, Aslım B (2012) Characterization of Pseudomonas spp. from seawater of the southwest coast of Turkey. J Biol Environ Sci 6: 15-23. 
Citation: El-Barbary MI, Hal AM (2017) Phenotypic and Genotypic Characterization of Some Pseudomonas sp. Associated with Burkholderia cepacia Isolated from Various Infected Fishes. J Aquac Res Development 8: 499. doi: 10.4172/2155-9546.1000499

52. Wiedmann M, Weilmeier D, Dineen SS, Ralyea R, Boor KJ (2000) Molecular and phenotypic characterization of Pseudomonas sp. isolated from milk. Appl Environ Microbiol 66: 2085-2095.

53. Kim MS, Jeong HD (2001) Development of 16 S rRNA targeted PCR methods for the detection and differentiation of Vibrio vulnificus in marine environments. Aquaculture 193: 199-211.

54. Tringe SG, Hugenholtz $P$ (2008) A renaissance for the pioneering 16 S rRNA gene. Curr Opin Microbiol 11: 442-446.

55. Tang J, Zheng A, Bromfield ESP, Zhu J, Li S, et al. (2011) 16S rRNA gene sequence analysis of halophilic and halotolerant bacteria isolated from a hypersaline pond in Sichuan, China. Ann Microbiol 61: 375-381.

56. Teng L, Hsueh P, Huang Y, Tsai J (2004) Identification of Bacteroides thetaiotaomicron on the basis of an unexpected specific amplicon of universal 16S ribosomal DNA PCR. J Clin Microbiol 42: 1727-1730.

57. Schleifer KH (2009) Classification of bacteria and archaea: Past, present and future. Syst Appl Microbiol 32: 533-542.

58. Markovic M, Radojicic M, Cosic S, Levnaic D (1996) Massive death of silver carp (Hypophthalmichthys molitrix Val.) and big head (Aristichthys nobilis Rich.) caused by Pseudomonas fluorescens bacteria. Vet Glas 50: 761-765.

59. Darak O, Barde RD (2015) Pseudomonas fluorescens associated with bacteria disease in Catla catla in Marathwada region Maharashtra. Intl J Adv Biotec Res 6: 189-195

60. Kumaran S, Deivasigamani B, Alagappan KM, Sakthivel M, Guru PS (2010) Isolation and characterization of Pseudomonas sp. KUMS3 from Asian sea bass (Lates calcarifer) with fin rot. World J Microbiol Biotechnol 26: 359-363. 